\title{
Edukacja zdrowotna - lokalne rozwiązania, globalne wyzwania. Przykłady dobrych praktyk w angielskich szkołach
}

\author{
Abstract \\ Health education - local solutions, global challenges. \\ Good practice examples in English schools
}

The paper presents health education, focusing on good practice examples in English schools. The first part contains a review of the education system in England, and basic principles of core curriculum of general education. It contains a description of concepts of health education in England with indications to core curricula of primary and secondary schools in the field of health education. The second part contains an overview of educational initiatives in Europe in the field of health education.

\section{Wprowadzenie}

Edukacja zdrowotna w szkołach jest okazją dla ucznia przyswojenia i praktykowania umiejętności, które mogą zapewnić sprawność i zdrowie przez całe życie. Istnieje wiele jej definicji. Jedna z nich, sformułowana przez Ministerstwo Edukacji Narodowej, wskazuje, że jest ona „procesem dydaktyczno-wychowawczym, w którym uczniowie uczą się jak żyć, aby zachować i doskonalić zdrowie własne i innych ludzi oraz tworzyć środowisko sprzyjające zdrowiu, a w przypadku choroby lub niepełnosprawności aktywnie uczestniczyć w jej leczeniu, radzić sobie 
i zmniejszać jej negatywne skutki"1. Podobnie jak Ministerstwo Edukacji Narodowej, Ośrodek Rozwoju Edukacji w definicji edukacji zdrowotnej wskazuje, że jest ona procesem, w toku którego uczniowie kształtują „nawyki dbałości o zdrowie własne i innych ludzi oraz umiejętności tworzenia zdrowego środowiska"2. Daje ona uczniom możliwość nabycia kompetencji (umiejętności, wiedzy i postaw), które są niezbędne do odpowiedzialnego uczestnictwa w życiu społecznym, ponieważ „(1) pomaga odkrywać, jakie wybory służą rozwojowi i lepszej jakości życia, (2) pomaga zrozumieć siebie i innych, (3) pomaga budować obraz świata, który jest najbliższy codziennym doświadczeniom, uczy odpowiedzialności, jest pierwszym stopniem profilaktyki różnych zagrożeń i zachowań problemowych"3.

Bez wątpienia zdrowie, definiowane przez Światową Organizację Zdrowia jako „dobrostan fizyczny, psychiczny i społeczny"4, oraz edukacja w ujęciu W. Okonia, rozumiana jako „ogół procesów i oddziaływań, których celem jest zmienianie ludzi stosownie do panujących w danym kraju ideałów i celów wychowawczych" (Okoń 2007, s. 93), są ze sobą powiązane. Barbara Woynarowska $(2011$, s. 7) wskazuje na trzy wymiary wzajemnej zależności tych zagadnień. Pierwszy z nich dotyczy edukacji jako zasobu dla zdrowia. Autorka powołuje się na badania wiążące poziom wykształcenia ludności z mniejszymi wskaźnikami umieralności i zachorowalności, mniejszą częstością chorób przewlekłych i zachowań ryzykownych (palenie tytoniu, nadużywanie alkoholu, nieprawidłowa dieta), dłuższym życiem. Drugi wymiar to zdrowie jako zasób dla edukacji. W tym przypadku zdrowie jest warunkiem rozpoczęcia przez dziecko nauki w szkole w określonym czasie i umożliwia regularne uczęszczanie do szkoły oraz satysfakcjonujące wyniki w nauce. Trzeci wymiar powiązania edukacji i zdrowia dotyczy podobieństw czynników wpływających na zdrowie i edukację. Wśród nich największy wpływ w odniesieniu do dzieci i młodzieży szkolnej mają czynniki społeczno-ekonomiczne rodziny, szkoła, środowisko lokalne, sieci społeczne, rówieśnicy.

W poniższym opracowaniu odniosę się do problematyki edukacji zdrowotnej, ze szczególnym uwzględnieniem dobrych praktyk stosowanych w angielskich szkołach. Na wstępie zaprezentuję ogólny przegląd systemu edukacji w Anglii, jak i rolę oraz założenia angielskiej podstawy programowej kształcenia ogólnego. Dalej omówię koncepcje edukacji zdrowotnej w Anglii oraz zaprezentuję wyniki analizy angielskich podstaw programowych kształcenia ogólnego szkół podstawowych i średnich I stopnia w zakresie edukacji zdrowotnej. W części drugiej dokonam ogólnego przeglądu inicjatyw oświatowych w Europie w odniesieniu do edukacji zdrowotnej. W zakończeniu znajdą się ogólne zalecenia dla celów i treści nauczania edukacji zdrowotnej, uwzględniające elementy edukacji globalnej.

1 Strona internetowa Ministerstwa Edukacji Narodowej www.men.gov.pl (data dostępu: 11.03.2015).

2 Strona internetowa Ośrodka Rozwoju Edukacji www.ore.edu.pl (data dostępu: 11.03.2015).

3 Tamże.

4 Strona internetowa Światowej Organizacji Zdrowia www.who.int (data dostępu: 11.03.2015). 


\section{Angielska podstawa programowa - przegląd ogólnych założeń}

Podstawa programowa w Anglii jest ważnym elementem systemu edukacji w tym kraju i obowiązuje na każdym szczeblu edukacji. Szkoły w Anglii, zarówno państwowe, jak i prywatne, zarządzane są przez Ministerstwo Edukacji (The Department for Education) oraz Ministerstwo ds. Biznesu, Innowacji i Umiejętności (Department for Business, Innovation and Skills) ${ }^{5}$. Do obowiązków Ministerstwa Edukacji należy między innymi planowanie i monitorowanie organizacji edukacji w szkołach oraz koordynacja polityki dotyczącej dzieci i młodzieży. Ministerstwo ds. Biznesu, Innowacji i Umiejętności jest odpowiedzialne przede wszystkim za innowacje w edukacji i szkolnictwie wyższym (Raport Eurydice 2011, s. 1).

Kształcenie obowiązkowe trwa w Anglii od 5. do 16. roku życia, przy czym dzieci mają możliwość rozpoczęcia nauki w klasie zerowej szkoły podstawowej w wieku 4 lat. Rok później uczniowie uczęszczają najpierw do szkoły podstawowej (primary school), a od 11. roku życia do szkoły średniej (secondary school). Wiele szkół średnich I stopnia prowadzi również kształcenie na poziomie średnim II stopnia dla uczniów w wieku od 16 lub 18 lat i powyżej.

Do 2011 roku w sprawach związanych z podstawą programową rządowi angielskiemu doradzała Agencja Rozwoju Kwalifikacji i Programów Nauczania (Qualifications and Curriculum Development Agency - QDCA). Rola QDCA podlega obecnie gruntownym zmianom, a odpowiedzialność za opracowanie programów nauczania przejęło Ministerstwo Edukacji (Raport Eurydice 2011, s. 1). Także od 2011 roku rozpoczęto reformę podstaw programowych kształcenia ogólnego. Celem zmian jest położenie nacisku na wiedzę z zakresu przedmiotów podstawowych, w mniejszym stopniu na zdobywanie ogólnych umiejętności uczenia się, jak i zmniejszenie zakresu zaleceń na poziomie centralnym, co daje szkołom więcej autonomii pod względem interpretacji podstawy programowej. Nowa podstawa programowa kształcenia ogólnego wprowadzana jest stopniowo. W pierwszej kolejności od września 2013 roku objęła przedmioty takie jak matematyka, język angielski, nauki ścisłe i przyrodnicze oraz wychowanie fizyczne, a od września 2014 roku obejmie pozostałe przedmioty nauczania.

Angielskie podstawy programowe kształcenia ogólnego są punktem wyjścia do samodzielnego opracowywania przez szkoły szczegółowych programów nauczania oraz do określenia szczegółowych treści i wyboru podręczników. Szkoła jest zobowiązana opracować szczegółowe plany nauczania każdego z przedmiotów, tj. plan długoterminowy (roczny), średnioterminowy (trzymiesięczny) i tygodniowy. Są one dokumentami, które mają gwarantować w Anglii w miarę spójne, porównywalne podstawy programowe, realizowane w szkołach w całym kraju.

5 W roku szkolnym 2001/2002 96\% uczniów uczęszczało do placówek państwowych, źródło: Eurydice. 


\section{Edukacja zdrowotna w Anglii}

Edukacja zdrowotna w angielskim systemie edukacji nie jest osobno nauczanym przedmiotem, a stanowi element innych obowiązkowych przedmiotów nauczania. Najczęściej występuje jako elementścieżki przedmiotowejo nazwie „Edukacja osobista, społeczna, zdrowotna i ekonomiczna" (Personal, Social, Health and Economic Education - PSHE), która jest realizowana na wszystkich etapach edukacji obowiązkowej w Anglii. PSHE w podstawie programowej zawiera jedynie ogólne wytyczne co do celów i treści przedmiotowych, a ich uszczegółowienie leży w gestii szkół, zobowiązanych tworzyć autorskie programy nauczania, według własnego pomysłu, uwzględniające potrzeby społeczności lokalnych, potrzeby i możliwości uczniów danej szkoły, dostępną bazę materialną, jak i charakter, specyfikę szkoły (The National Curriculum for England 2013, s. 5).

Ministerstwo ds. Edukacji Anglii (Department for Education) we wstępie do krajowej podstawy programowej zawarło stwierdzenie, że to nauczyciele uczący w konkretnej szkole najlepiej znają uczniów i to dlatego oni są w stanie najlepiej zrozumieć potrzeby i możliwości uczniów i nie potrzebują wytycznych ministerialnych. Dlatego też w ich gestii pozostaje decyzja odnośnie uszczegółowienia treści przedmiotowych. Nauczyciele mają też pełną swobodę w zakresie decydowania nie tylko o celach i treściach ścieżek edukacyjnych, ale i pojedynczych przedmiotów szkolnych oraz o wymiarze godzinowym.

Aby wspomóc szkoły w tworzeniu szkolnych programów PSHE, Ministerstwo ds. Edukacji utworzyło specjalną platformę internetową ${ }^{6}$, na której zawarło informacje pomocne w konstruowaniu programów edukacji zdrowotnej. Strona ta oferuje nauczycielom także wymianę opinii na temat praktyki edukacyjnej. Jest też bazą dobrych praktyk, jeśli chodzi o materiały opisujące doświadczenia szkół, oferując różne możliwości promowania sprawdzonych rozwiązań i upowszechnianie zastosowanych rozwiązań w zakresie PSHE. Także realizowanej w ramach edukacji zdrowotnej profilaktyce antynarkotykowej poświęcono osobne miejsce w Internecie. Na stronie Mentor ADEPSIS ${ }^{7}$ znajdują się przykłady stosowanych w szkołach rozwiązań skoncentrowanych na profilaktyce uzależnień. Działania w jej ramach, w swoim założeniu, powinny wspomagać prawidłowe procesy rozwoju fizycznego i psychicznego oraz mają na celu promocję zdrowego stylu życia.

\footnotetext{
6 www.pshe-association.org.uk (data dostępu: 11.03.2015).

7 www.mentor-adepsis.org (data dostępu: 11.03.2015).
} 


\section{Edukacja zdrowotna w angielskiej podstawie programowej kształcenia ogólnego}

W podstawie programowej PSHE wyodrębniono edukację zdrowotną i wyeksponowano potrzebę refleksji nad niebezpieczeństwami i wyzwaniami związanymi ze zdrowiem i życiem wspólnym z innymi, rozwijaniem wiedzy i umiejętności życiowych oraz społecznych, które pozwolą uczniom radzić sobie z wymogami życia, emocjami, dokonywać świadomych i odpowiedzialnych decyzji w wymiarze lokalnym i globalnym. Treści kształcenia powinny uwzględniać zagadnienia w zakresie profilaktyki antynarkotykowej, znaczenia aktywności i zbilansowanej diety dla zdrowia.

Elementy edukacji zdrowotnej w Anglii są częścią treści nauczania przedmiotów takich jak przyroda (szkoła podstawowa i średnia), technologie i projektowanie (szkoła podstawowa) oraz edukacja fizyczna (szkoła podstawowa i średnia). W podstawie programowej przyrody obowiązującej w szkole podstawowej na uwagę (z punktu widzenia występujących w niej elementów edukacji zdrowotnej) zasługuje dział tematyczny „Życie w naturalnym środowisku”. W celach kształcenia znajdują się odniesienia do rozwijania umiejętności intelektualnych, analizowania związków i zależności pomiędzy dietą, niezdrowym odżywianiem a aktywnością fizyczną oraz narkotykami i zdrowym stylem życia. Z kolei w szkole średniej większy nacisk kładzie się na rozwijanie właściwych nawyków żywieniowych, jak i ukierunkowanie na uczenie się o zdrowiu i chorobach. W The National Curriculum for England (2013, s. 60) możemy przeczytać, że uczniowie poznają istotę zbilansowanej diety, jej optymalny skład, kształtują praktyczne umiejętności obliczania wymagań energetycznych w codziennej diecie, a ponadto kształtują umiejętności rozumienia wagi zdrowego stylu życia, podając przykłady zdrowej i zróżnicowanej diety wraz z ich uzasadnieniem (s. 61). Dokonują też refleksji na temat wpływu narkotyków i innych używek na zdrowie i życie człowieka (s. 62). Ważnym zagadnieniem tematycznym w szkole średniej są choroby - nie tylko te powstałe w wyniku nieprawidłowego odżywiania się, ale też choroby przekazywane drogą płciową (s. 63). Co ciekawe, w celach nauczania eksponuje się praktyczne umiejętności przygotowywania zdrowych posiłków.

Oprócz przedmiotu „Przyroda” elementy edukacji zdrowotnej w angielskiej podstawie programowej można odnaleźć w celach i treściach wychowania fizycznego. Celem ogólnym tego przedmiotu w szkole podstawowej i średniej jest inspirowanie zdrowym stylem życia i aktywnością fizyczną. Sport w szkole powinien stać się okazją dla ucznia do rozwijania potrzeby dbania o zdrowie i sprawność fizyczną. Innymi celami odnoszącymi się do edukacji zdrowotnej są: rozwijanie kompetencji w zakresie różnych dyscyplin sportowych, kształtowanie potrzeby utrzymania aktywności fizycznej oraz zaangażowania w rywalizację sportową, jak i prowadzenie zdrowego, aktywnego trybu życia (s. 198). Oprócz „Przyrody” przedmiotem nauczania w szkole podstawowej, którego cele odnoszą się do edukacji zdrowotnej w Anglii, są „Technologie i projektowanie”. Celem ogólnym tego 
przedmiotu jest kształtowanie w uczniach praktycznych umiejętności potrzebnych w życiu codziennym. Uczniowie uczą się przygotowywać posiłki, znając zasady zdrowej i zbilansowanej diety (s. 183).

\section{Wychowanie fizyczne i edukacja zdrowotna w Europie - ogólny przegląd inicjatyw oświatowych}

Przedstawione rozwiązania w zakresie edukacji zdrowotnej w Anglii odzwierciedlają jedną z możliwości realizowania edukacji zdrowotnej w szkołach, które mogą być uznane za przykład dobrych praktyk. Uważam, że warto przyjrzeć się też rozwiązaniom stosowanym w innych krajach, zyskując szerszy pogląd na wyzwania stojące przed edukacją zdrowotną nie tylko w wymiarze lokalnym, ale też globalnym.

Podobnie jak w Anglii edukacja zdrowotna w europejskich programach nauczania nie jest osobnym przedmiotem, a częścią różnych obowiązkowych przedmiotów nauczania, najczęściej wychowania fizycznego. Wyjątek stanowią takie kraje, jak Cypr, Finlandia i Irlandia. Treści tematyczne edukacji zdrowotnej obejmują najczęściej takie zagadnienia, jak dobre samopoczucie fizyczne oraz psychiczne, zdrowie i zapobieganie chorobom, higiena, bezpieczeństwo, zdrowie seksualne, odżywianie, szkody zdrowotne i społeczne, np. te związane z nadużywaniem alkoholu, papierosów, narkotyków (Raport Eurydice 2014, s. 22).

Charakterystyczne dla celów ogólnych edukacji zdrowotnej realizowanej w ramach zajęć sportowych w Europie jest rozwój sprawności fizycznej oraz umiejętności emocjonalnych i fizycznych, z uwzględnieniem kształtowania motywacji oraz sfery etycznej. Z raportu Eurydice „Wychowanie fizyczne i sport w szkołach w Europie" (2014) wynika, że w zakresie rozwoju fizycznego i motorycznego w podstawach programowych eksponuje się umiejętności koordynacji psychoruchowej, jak i wytrzymałość, gibkość, równowagę. Ponadto kładzie się nacisk na kształtowanie nawyków związanych z utrzymywaniem prawidłowej postawy. Nie mniej istotna jest też edukacja zdrowotna. Lekcje wychowania fizycznego są okazją do promowania wśród uczniów zdrowia i zdrowego trybu życia, odczuwania radości z uprawiania ćwiczeń, rozwijania postaw prozdrowotnych, wartości zdrowia dla funkcjonowania w społeczeństwie (s. 17).

Oprócz rozwoju fizycznego ważne miejsce w celach kształcenia europejskich programów nauczania zajmuje rozwój osobisty. Dużą wagę przywiązuje się do kształtowania w uczniach pewności siebie, poczucia odpowiedzialności, cierpliwości i odwagi, samoakceptacji oraz tolerancji dla odmienności. Kluczowym elementem rozwoju osobistego w ramach zajęć sportowych w szkole jest odkrywanie sposobów radzenia sobie z negatywnymi emocjami i stresem. W angielskiej podstawie programowej eksponuje się wychowanie fizyczne jako przedmiot szczególnej wagi w zakresie uczenie się współzawodnictwa. Uczniowie poznają zasady fair play, uczestnicząc w zajęciach sportowych w szkole, w turniejach międzyszkolnych. Kształtują przy tym umiejętności planowania, oceny, wersyfikacji podejmowanych wysiłków. 
Równie ważny jak rozwój fizyczny i osobisty jest rozwój społeczny poprzez sport. Często w celach nauczania europejskich programów nauczania podkreśla się rozwijanie postaw solidarności, współpracy w zespole, poszanowania reguł, szacunku dla innych. W krajach takich jak Dania mówi się o zwiększaniu „świadomości odpowiedzialności za własne życie wśród dzieci i młodzieży” oraz o zapobieganiu przemocy (s. 18). Krajowe programy nauczania obowiązujące w Czechach, Estonii i na Węgrzech zachęcają młodych ludzi do kibicowania, interesowania się sportem i uczestnictwem w zawodach sportowych (s. 19).

\section{Podsumowanie}

Edukację zdrowotną warto rozpatrywać nie tylko w kontekście lokalnych rozwiązań, ale włączyć w nią również treści o znaczeniu globalnym. Uważam, że w celach kształcenia edukacji zdrowotnej należałoby zwrócić większą uwagę na kształtowanie w uczniach refleksji na tematy związane ze zdrowiem, ukazując główne problemy i wyzwania na naszym globie. Edukacja zdrowotna powinna rozwijać umiejętności współzawodnictwa, wrażliwość społeczną oraz poczucie więzi ze wspólnotą lokalną, narodową, europejską i globalną. Cele kształcenia powinny eksponować umiejętności rozpoznawania sytuacji zagrażających zdrowiu i życiu człowieka na świecie oraz działań zwiększających bezpieczeństwo własne i każdego innego człowieka, a także rozpoznawania i analizowania pozytywnego i negatywnego wpływu środowiska na zdrowie człowieka. Uczeń powinien interpretować informacje, oceniać, wyrażać opinie na temat zagadnień związanych ze zdrowiem i jego wpływem na środowisko przyrodnicze w swojej okolicy i w szerszej perspektywie globalnej, analizować związki pomiędzy zdrowiem a zagadnieniem zrównoważonego rozwoju.

Treści edukacji zdrowotnej mają znaczenie w promocji zdrowia i profilaktyce zachowań ryzykownych w każdym miejscu na naszej planecie. Ujawnia się tym samym potrzeba szerszej globalnej strategii działań na rzecz zdrowia, dzięki której ludzie zyskują odpowiednie kompetencje, pozwalające im na dokonywanie zmian w swoim środowisku i stylu życia. Jednym z elementów treści nauczania, które można włączyć do programów edukacji globalnej, mogłaby się stać wiedza na temat zagrożeń związanych ze zdrowiem nie tylko w odniesieniu do własnego kraju, ale też wiedza o zagrożeniach w innych częściach świata. Tematyka mogłaby odnosić się także do wiedzy na temat działalności Światowej Organizacji Zdrowia, międzynarodowej polityki zdrowotnej, globalnych programów zdrowotnych, a także problemów i potrzeb państw rozwijających się (w tym na przykład nadzór nad epidemiami, szczepienia ochronne, walka z chorobami zakaźnymi).

Ścieżka edukacyjna „Edukacja zdrowotna” oraz określenie celów i treści nauczania w podstawie programowej stwarzają nowe szanse przed edukacją zdrowotną, stając się jednocześnie wyzwaniem dla nauczycieli różnych przedmiotów szkolnych, nie tylko w naszym kraju lub w Anglii. Elementy edukacji zdrowotnej w celach kształcenia różnych przedmiotów szkolnych w Anglii, jak przedstawiłam powyżej, ukazują możliwości jej wykorzystania i zastosowania w toku edukacji 
obowiązkowej, wiążąc ją nie tylko z wychowaniem fizycznym, ale także z takimi przedmiotami nauczania, jak przyroda, technologie i projektowanie. Teoretycy kształcenia i wychowania są zgodni, że spośród różnych czynników decydujących o jakości i efektywności pracy szkoły najważniejszym jest niewątpliwie nauczyciel. Edukacja zdrowotna uwzględniona w podstawie programowej Anglii jest ciekawym przykładem dobrych praktyk stosowanych w innych krajach. Jednym z wyzwań, jakie stoją przed ich twórcami, jest poszerzenie treści tematycznych o zagadnienia edukacji globalnej.

Tabela 1. Elementy edukacji zdrowotnej w angielskiej podstawie programowej kształcenia ogólnego

(The National Curriculum for England, Primary School)

\begin{tabular}{|c|c|}
\hline Przedmiot szkolny & $\begin{array}{l}\text { Odniesienie w podstawie programowej } \\
\text { w zakresie edukacji zdrowotnej }\end{array}$ \\
\hline \multicolumn{2}{|r|}{ Szkoła podstawowa } \\
\hline Przyroda & $\begin{array}{l}\text { Dział tematyczny: Życie w naturalnym środowisku. } \\
\text { Uczniowie powinni: } \\
\text { - analizować związki i zależności pomiędzy zdrowym stylem } \\
\text { życia a niezdrową dietą, aktywnością fizyczną, narkotykami } \\
\text { (The National Curriculum for England, Primary School, } \\
\text { s. 173). }\end{array}$ \\
\hline Technologie i projektowanie & $\begin{array}{l}\text { Dział tematyczny: Gotowanie i odżywianie. } \\
\text { Uczniowie powinni: } \\
\text { - stosować podstawowe zasady przygotowywania zdrowych } \\
\text { posiłków, } \\
\text { - rozumieć i stosować przykłady zdrowej i zróżnicowanej diety. }\end{array}$ \\
\hline Edukacja fizyczna & $\begin{array}{l}\text { Edukacja fizyczna w szkole powinna być dla ucznia inspiracją } \\
\text { do prowadzenia zdrowego stylu życia oraz podejmowania ak- } \\
\text { tywności fizycznej. Celem zajęć z wychowania fizycznego jest } \\
\text { rozwijanie potrzeby dbania o zdrowie oraz sprawność fizyczną. } \\
\text { Cele ogólne przedmiotu: } \\
\text { - rozwijanie kompetencji w zakresie różnych dyscyplin sporto- } \\
\text { wych, } \\
\text { - kształtowanie potrzeby utrzymania aktywności fizycznej, } \\
\text { - zaangażowanie w rywalizację sportową, } \\
\text { - kształtowanie w uczniach potrzeby zdrowego, aktywnego } \\
\text { trybu życia (The National Curriculum for England, Primary } \\
\text { School, s. 198). }\end{array}$ \\
\hline \multicolumn{2}{|r|}{ Szkoła średnia } \\
\hline Przyroda & $\begin{array}{l}\text { Dział tematyczny: Odżywianie i trawienie } \\
\text { - zawartość zbilansowanej diety człowieka: karbohydraty, lipidy } \\
\text { (tłuszcze i oleje), proteiny, witaminy, minerały, woda - dlacze- } \\
\text { go zbilansowana dieta jest potrzebna, }\end{array}$ \\
\hline
\end{tabular}


Tabela 2 (cd.)

\begin{tabular}{|c|c|}
\hline Przedmiot szkolny & $\begin{array}{l}\text { Odniesienie w podstawie programowej } \\
\text { w zakresie edukacji zdrowotnej }\end{array}$ \\
\hline Przyroda & $\begin{array}{l}\text { - kalkulowanie wymagań energetycznych w codziennej zbilan- } \\
\text { sowanej diecie, } \\
\text { - konsekwencje nierównowagi w diecie (głodówki, schorzenia etc.), } \\
\text { - tkanki, organy, włącznie z wpływem na nie różnych diet i funk- } \\
\text { cjonowaniem układu trawiennego (w tym enzymy, bakterie etc.) } \\
\text { (The National Curriculum for England, Primary School, s. 173). } \\
\text { Dział tematyczny: Zdrowie } \\
\text { - oddziaływanie narkotyków na zachowanie, zdrowie i procesy } \\
\text { życiowe*. } \\
\text { Dział tematyczny: Zdrowie, choroby, rozwój medycyny } \\
\text { - związek pomiędzy zdrowiem i chorobami, } \\
\text { - choroby zakaźne, włącznie z chorobami przekazywanymi } \\
\text { drogą płciową (HIVIAIDS), } \\
\text { - wpływ stylu życia na choroby niezakaźne (The National Curri- } \\
\text { culum for England, Primary School, s. 62). } \\
\text { Dział tematyczny: Gotowanie i odżywianie. } \\
\text { Uczniowie powinni: } \\
\text { - stosować podstawowe zasady przygotowywania zdrowych } \\
\text { posiłków, } \\
\text { - rozumieć i stosować przykłady zdrowej i zróżnicowanej diety } \\
\text { (The National Curriculum for England, Primary School, s. 90). }\end{array}$ \\
\hline Edukacja fizyczna & $\begin{array}{l}\text { Edukacja fizyczna w szkole powinna być dla ucznia inspiracją } \\
\text { do prowadzenia zdrowego stylu życia oraz podejmowania ak- } \\
\text { tywności fizycznej. Celem zajęć z wychowania fizycznego jest } \\
\text { rozwijanie potrzeby dbania o zdrowie oraz sprawność fizyczną, } \\
\text { jak i kształtowanie wartości takich jak uczciwość, sprawiedli- } \\
\text { wość, szacunek. } \\
\text { Cele ogólne przedmiotu: } \\
\text { - rozwijanie kompetencji w zakresie różnych dyscyplin sportowych, } \\
\text { - kształtowanie potrzeby utrzymania aktywności fizycznej, } \\
\text { - rozwijanie zaangażowania w rywalizację sportową, } \\
\text { - prowadzenie zdrowego, aktywnego trybu życia (The National } \\
\text { Curriculum for England, Primary School, s. 102). }\end{array}$ \\
\hline
\end{tabular}

* Źródło: tamże, s. 61.

\section{Literatura}

Białek E.D., Edukacja zdrowotna w praktyce, Wydawnictwo Instytutu Psychosytnezy, Warszawa 2011. Bulska J., Budowanie kompetencji zdrowotnych ludzi w środowisku ich życia: propozycje metodyczne dla pedagogów, nauczycieli, wychowawców i pracowników medycznych, wskazówki dla rodziców, Wydawnictwo Edukacyjne Akapit, Toruń 2008.

Dixon M., System edukacji w Wielkiej Brytanii, [w:] H. Bednarczyk (red.), Podstawy teoretyczne i modele systemów zarządzania w ustawicznej edukacji zawodowej, Wydawnictwo PIB, Radom 2005, s. 81-92.

Dziubiński Z., Rymarczyk P., Kultura fizyczna a globalizacja, Wydawnictwo Akademii Wychowania Fizycznego J. Piłsudskiego w Warszawie, Warszawa 2010. 
Okoń W., Nowy słownik pedagogiczny, Wydawnictwo Akademickie Żak, Warszawa 2007.

Potulicka E., Nowy kanon edukacji obowiązkowej w Anglii, [w:] R. Leppert (red.), Edukacja w świecie współczesnym: wybór tekstów z pedagogiki porównawczej wraz z przewodnikiem bibliograficznym i przewodnikiem internetowym, Wydawnictwo Impuls, Kraków 2000, s. 299-319.

Raport Eurydice: Wychowanie fizyczne i sport w szkołach w Europie, Wydawnictwo Fundacji Rozwoju Systemu Edukacji, Warszawa 2014.

Syrek E., Borzucka-Sitkiewicz K., Edukacja zdrowotna, Wydawnictwo WAiP, Warszawa 2009.

Strona internetowa Ministerstwa Edukacji Anglii. The National Curriculum for England, Secondary School, Department for Education, www.gov.uk/government/publications/national-curriculum-inengland-secondary-curriculum (data dostępu: 24.03.2015).

Strona internetowa Ministerstwa Edukacji Narodowej, http://men.gov.pl/zwiekszanie-szans/promocja-zdrowia/c164-informacje-materialy/edukacja-zdrowotna.html (data dostępu: 24.03.2015).

Strona internetowa Ośrodka Rozwoju Edukacji, www.ore.edu.pl (data dostępu: 25.03.2015).

Strona internetowa Światowej Organizacji Zdrowia, www.who.int (data dostępu 11.03.2015).

Woynarowska B., Edukacja zdrowotna. Podręcznik akademicki, Wydawnictwo Naukowe PWN, Warszawa 2010.

Woynarowska B., Organizacja i realizacja edukacji zdrowotnej w szkole. Poradnik dla dyrektorów szkół i nauczycieli, Wydawnictwo Ośrodka Rozwoju Edukacji, Warszawa 2011. 